\title{
PENERAPAN PENGENDALIAN ERGONOMIK DAN PENCEGAHAN \\ HAZARD PSIKOSOSIAL
}

\author{
Sri Raudatul Jannah \\ $\underline{\text { Raudatuljannahsri@gmail.com }}$
}

\section{Latar Belakang}

Setiap pekerjaan memiliki potensi bahaya (hazard). Apabila potensi bahaya tidak diperhatikan dan dikendalikan, bisa berpotensi menyebabkan terjadinya kelelahan, keluhan muskulosekeletal, cedera, bahkan mungkin terjadi kecelakaan kerja. Maka dari itu perlu dilakukan pengendalian bahaya dengan menemukan potensi bahaya yang ada pada area kerja, lalu dilakukan identifikasi bahaya. Selanjutnya setelah berhasil melakukan identifikasi sumber bahaya yang ada, maka perlu dievaluasi tingkat resikonya terhadap para pekerja. Dengan begitu hal-hal yang tidak diharapkan dari peristiwa kecelakaan kerja bisa dicegah.

Penyebab dari kecelakaan kerja bisa datang kapan, di mana dan kepada siapa saja, terhadap yang beresiko mengalami kecelakaan kerja yang ditimbulkan karena faktor kesengajaan atau tidak. Menurut Lestari, Trisyulianti (2009) Keselamatan dan Kesehatan Kerja (K3) adalah suatu program yang dibuat pekerja maupun pengusaha sebagai upaya mencegah timbulnya kecelakaan dan penyakit akibat kerja, dengan cara mengenali hal-hal yang berpotensi menimbulkan kecelakaan dan penyakit akibat kerja serta tindakan antisipatif apabila terjadi kecelakaan dan penyakit akibat kerja. Tujuan dari dibuatnya program K3 adalah untuk mengurangi biaya perusahaan apabila timbul kecelakaan dan penyakit akibat kerja.

Ergonomi adalah studi ilmiah yang mempelajari hubungan antara manusia dan tempat kerja. Ergonomi memungkinkan desainer dan insinyur untuk membuat sistem kerja yang tepat dan sesuai pengukuran untuk dapat digunakan manusia. Posisi yang ergonomi saat lah penting dalam melakukan pekerjaan serta menghindari dari kemudahan lelah saat bekerja serta yang dapat menimbulkan penyakit.

Psikososial adalah hubungan antara kondisi sosial seseorang atau pekerja dengan kesehatan mental/emosionalnya. Hazard psikososial adalah suatu bentuk bahaya yang dapat mengancam kesehatan mental para pekerja dan risiko penurunan produktifitas pekerja. 
Dikarenakan hal tersebut upaya atau pencegahan pada hazard psikososial yang akan dibahas ini menjadi hal penting selain melindungi atau mencegah bahaya fisik atau luar lainnya.

Psiklogis merupakan salah satu risiko psikososial utama dalam pekerjaan dan mengacu pada aspek pekerjaan yang akan membutuhkan usaha mental atau emosional. Meskipun tidak selalu negatif, tuntutan pekerjaan psikologis dapat memicu reaksi ketegangan dan stres ketika mereka membutuhkan terlalu banyak usaha. Jika berkelanjutan, psikologis tuntutan pekerjaan dapat mengakibatkan sakit (Niedhammer, Chastang, Sultan-Taieb, Vermeylen, \& Parent-Thirion, 2012).

Keyword : Pengendalian Ergonomik, Hazard Psikosoaial

\section{Metode}

Metode yang digunakan pada penelitian ini adalah metode kualitatif yaitu penelitian yang digunakan untuk meneliti pada kondisi objek alamiah, dimana peneliti merupakan instrumen kunci (Sugiyono, 2005). Serta dengan menggunakan analisa dari berbagai referensi seperti buku atau jurnal dan berfokus pada metode pembelajaran mengenai peran perawat tentang insiden yang terjadi dalam keselamatan paisen di rumah sakit. Referensi adalah sesuatu yang dipakai dalam pemerian informasi untuk memperkuat pernyataan dengan tegas, atau sering disebut juga dengan "rujukan". Sumber materi referensi ialah tempat materi itu ditemukan.

Dalam pengambilan data yang dilakukan secara menganalisa data dari beberapa jurnal yang ada serta mendapatkan referensi gabungan yang di tuangkan dalam jurnal ini. Sumber yang digunkan adalah sumber yang terbit dari mulai tahun 2012 hingga sekarang.

\section{Hasil}

Posisi kerja duduk merupakan postur kerja yang umum ditemukan pada industri, khususnya industri kecil. Hasil riset ergonomi menyatakan posisi kerja duduk lebih dipilih untuk digunakan dibanding postur kerja berdiri, terlebih untuk pekerja wanita (Lehto \& Buck, 2008).

Ergonomi menjadi pilar kesehatan dan menjadi salah satu indikator kesejahteraan. Menurut Meily (2013), perbaikan ergonomi perlu dilakukan sebagai salah satu upaya 
pencegahan terhadap penyakit CTDs (Cumulative Trauma Disorders) akibat faktor risiko kerja postur janggal, beban, frekuensi dan durasi yang bersumber dari pekerjaan, seperti nyeri tengkuk, nyeri pinggang bawah atau low back pain, rasa baal pada jari telunjuk, jari tengah dan jari manis yang disertai nyeri terbakar pada malam hari, kekakuan, lemah dan nyeri saat tangan digunakan dan dikenal dengan nama Carpal Tunnel Syndrome.

Bahaya Psikososial merupakan bahaya pekerjaan yang memengaruhi kesejahteraan psikologis pekerja termasuk kemampuan untuk berpartisipasi dalam lingkungan kerja diantara orang lain Petugas kesehatan mengalami kelelahan emosional yang berdampak padas stress kerja dan mungkin berdampak lebih sehingga dapat mengalami burnout. Menurut Lubis (2009) burnout adalah keadaan seseorang di tempat kerja yang ditandai dengan menurunnya produktivitas karena stres ditempat kerja secara terus menerus, yang ditandai dengan gejala depresi.

Faktor psikososial sering dinyatakan dengan bagaimana pandangan pekerja maupun manajer terhadap organisasi kerja yang dilaksanakan di tempat kerjanya. Organisasi kerja dilaksanakan di tempat kerja adalah untuk melaksanakan proses produksi, yang harus diikuti oleh para pekerja, pengawas, mandor maupun para manajer. Untuk meminimalisir dampak buruk dari faktor psikososial di tempat kerja, sebaiknya perusahaan mengupayakan sistem reward baik berupa materi maupun apresiasi terhadap hasil kerja untuk meningkatkan motivasi bagi pekerja serta menciptkan komunikasi secara lebih aktif antara manajemen dengan pekerja. Serta dapat memahami tindakan atau memberi pengarahan dalam menangani stres yang di terima pekerja atau perawat di suatu unit perusahaan maupun rumah sakit.

Serta untuk menagani psikososial untuk seorang perawat maupun pekerja bisa melakukan hal-hal yang disenangi dan diinginkan untuk mengatasi stres yang dapat brdampak pada pekerjaan dan kehidupan sehari-hari. Dan juga dapat menenagkan pikiran dengan melakukan hal-hal yang membuat tenang pikiran, serta menghindari suatu tindakan atau pekerjaan yang dapat menimbulkan emosi maupun kekesalan terhadap sesuatu.

\section{Pembahasan}

Bahaya kesehatan dapat menyebabkan penyakit yang disebabkan oleh pekerjaan suatu sumber bahaya di tempat kerja. Potensi bahaya kesehatan biasanya berasal dari lingkungan kerja diantaranya faktor kimia, faktor fisik, faktor biologi, faktor ergonomis, dan faktor psikologi. Maka dari itu Keselamatan dan Kesehatan Kerja sangat penting untuk kepentingan diri sendiri dan lingkungan tempat kita bekerja. 
Menurut Lestari, Trisyulianti (2009) adalah suatu program yang dibuat pekerja maupun pengusaha sebagai upaya mencegah timbulnya kecelakaan dan penyakit akibat kerja, dengan cara mengenali hal-hal yang berpotensi menimbulkan kecelakaan dan penyakit akibat kerja serta tindakan antisipatif apabila terjadi kecelakaan dan penyakit akibat kerja. Lebih lanjut Lestari, Trsyulianti (2009) menyatakan bahwa tujuan dari dibuatnya program K3 adalah untuk mengurangi biaya perusahaan apabila timbul kecelakaan dan penyakit akibat kerja.

Menurut Hamali (2016) keselamtan dan kesehatan kerja telah menjadi perhatian di kalangan pemerintahan dan pelaku bisnis sejak lama. Faktor keselamatan kerja menjadi penting karena sangat terkait dengan kinerja karyawan dan pada gilirannya terhadap kinerja perusahaan. Fasilitas keselamatan kerja yang tersedia di perusahaan akan membuat semakin sedikit kemungkinan terjadinya kecelakaan kerja.

Menurut Restuputri \& Sari (2015), menyatakan bahwa untuk mengurangi atau menghilangkan bahaya yang dapat menyebabkan kecelakaan di tempat kerja maka diperlukan suatu manajemen risiko kegiatannya meliputi identifikasi bahaya, analisis potensi bahaya, penilaian risiko, pengendalian risiko, serta pemantauan dan evaluasi. Dalam proses identifikasi dan melakukan analisis potensi bahaya dapat menggunakan metode Hazard and Operability study (HAZOP).

Penilaian risiko adalah analisis sistematis untuk mengidentifikasi atau mengukur frekuensi atau probabilitas dan besarnya kerugian kepada penerima karena paparan bahaya (fisik, kimia, biologi, ergonomi dan psikososial) kegagalan yang melibatkan peristiwa terhadap manusia.(15) Berdasarkan penilaian risiko dengan hasil kali dari Likelihood (L) dan Severity (S) didapatkan bahwa dilakukan penilaian risiko terhadap unit kerja didapatkan bahaya fisik risiko tinggi yang terdapat hampir pada semua unit yang dapat menyebabkan kecelakaan kerja yang didominasi oleh pasien yang berusaha menerkam sehingga dapat menyebabkan luka akibat gigitan dan cakaran pada petugas, peristiwa tersebut disebabkan petugas melakukan tindakan tanpa bantuan petugas lain serta kekurangan pekerja pada rumah sakit adalah salah satu faktor yang berpengaruh.

Erginomi adalah studi ilmiah yang mempelajari hubungan antara manusia dan tempat kerja. Ergonomi memungkinkan desainer dan insinyur untuk membuat sistem kerja yang tepat dan sesuai pengukuran untuk dapat digunakan manusia.

Bahaya ergonomi yang telah diidentfikasi yang berasal dari kurangnya kebutuhan luas ruang kerja sehingga memengaruhi petugas dalam bergerak dan penempatan kandang yang dalam ruang kerja juga berpengaruh untuk mempersempit ruang gerak petugas dalam hal ini 
dapat menyebabkan risiko untuk tersandung kandang saat melakukan kegiatan di ruang tersebut, untuk potensi bahaya ergonomi lainnya letak antara ruang tindakan dan tempat persiapan alat kerja cukup jauh sehingga membuat petugas bolak balik untuk mengambil peralatan yang tertinggal,yang dapat menimbulkan masalah ergonomi lainnya pada Rumah Sakit.

Dalam ergonomi, postur tubuh adalah faktor yang sangat penting, salah satunya postur duduk yang setiap orang lakukan setiap hari dalam durasi berjam-jam. Tujuan utama membuat desain ergonomi untuk kursi atau tempat duduk dan meja adalah menciptakan sedemikian rupa bentuk kursi dan meja belajar, sehingga dapat mempertahankan postur tulang punggung yang fi siologis, dengan demikian diharapkan kerja otot tidak perlu berkontraksi secara berlebihan (Meily, 2013).

Masalah ketidak sesuaian aspek ergonomi antara sarana kerja dan manusia serta pengaruhnya terhadap kesehatan belum mendapatkan perhatian yang serius di Indonesia. Hal ini terbukti dengan masih banyaknya tempat-tempat kerja yang belum berpedoman dengan kaidah ergonomi dalam hal penyediaan peralatan kerja bagi tenaga kerja (Turmuzi, 2013).

Perawat perlu untuk mengetahui prinsip ergonomis di tempat kerja yang dapat membantu perawat untuk menghindari faktor resiko tertentu yang berkontribusi pada gangguan muskuloskletal dan meningkatkan keselamatan dan kesehatan di tempat kerja. Pengetahuan ergonomi memengarusi sikap kerja saat melakukan tindakan keperawatan terutapa para saat melakukan tindakan keperawatan yang membutuhkan fokus dan durasi waktu lama, bahkan yang sering di lakukan dengan sikap kerja tidak ergonomis tanpa perawat sadari.

Posisi kerja dapat diperbaiki dengan mempertimbangkan penggunaan fasilitas kerja berupa meja dan kursi yang ergonomis. Permukaan kerja (work surface) perlu dirancang sedemikian rupa sehingga pekerja tidak mengalami permasalahan dalam menangani pekerjaan. Area kerja utama harus ditempatkan tepat di depan pekerja untuk menghindari perputaran punggung saat beraktivitas (Bridger, 2003).

Menurut Sidabutar, Dharmawan, dan Poerwandari (2003) definisi psikososial adalah hubungan yang dinamis antara kondisi psikologis dan sosial individu. Perilaku individu memiliki kaitan erat dengan keadaan psikologisnya maupun keadaan sekitarnya atau kondisi sosial. Bahaya psikososial di tempat kerja dapat didefinisikan sebagai aspek -aspek dari desain kerja, organisasi kerja dan manajemen kerja, serta segala aspek yang berhubungan dengan 
lingkungan sosial kerja yang berpotensi dapat menyebabkan gangguan pada psikologi dan fisik-fisiologis kerja (Cox \& Griffiths, 2000).

Menurut Kementerian Kesehatan (dalam Malik, 2016), faktor psikososial dapat mengakibatkan perubahan dalam kehidupan individu, baik bersifat psikologis maupun sosial yang mempunyai pengaruh cukup besar sebagai faktor penyebab terjadiya gangguan fisik dan psikis pada diri individu tersebut. Faktor psikososial sering tidak disadari kehadirannya oleh para pekerja. Kajian mengenai faktor psikososial di tempat kerja juga masih belum banyak dilakukan.

Dampak negatif dari psikososial merupakan salah satu jenis bahaya yang berpotensi mengakibatkan gangguan kesehatan di tempat kerja (Jeyaratnam \& Koh, 2009).

Berdasarkan aspek lingkungan kerja dapat dikatakan bahwa faktor fisik dan faktor kimia di lingkungan kerja dapat menimbulkan faktor psikososial bagi karyawan. Faktor fisik tersebut antara lain noise (suara bising), temperature (suhu), clean lines (kebersihan tempat kerja), faktor kimia dust (debu) dan gas. Beberapa permasalahan dalam lingkungan kerja fisik mempengaruhi kesehatan karyawan sehingga memunculkan simptom-simtom gangguan kesehatan mulai dari yang ringan hingga berat (Aronsson, Gustafsson, \& Dallner, 2002).

Masalah psikososial merupakan masalah psikis atau kejiwaan yang timbul sebagai akibat terjadinya perubahan sosial. Oleh karena itu, masalah atau bahaya psikososial dapat terjadi sebagai akibat atau dampak negatif dari adanya proses interaksi sosial seseorang yang buruk. Resiko kerja dan gangguan kesehatan tersebut dapat merugikan para pekerja, yang dapat mengakibatkan pekerja meninggal, keracunan, cacat dan mengidap penyakit kronis sehingga tidak mampu lagi untuk bekerja. Untuk meminimalisasi terjadinya penyakit akibat kerja, maka perlu dilakukan identifikasi bahaya, dimana penyakit akibat kerja bisa disebabkan oleh perilaku pekerja dan kondisi tempat kerja yang kurang baik.

Serta untuk menagani psikososial untuk seorang perawat maupun pekerja bisa melakukan hal-hal yang disenangi dan diinginkan untuk mengatasi stres yang dapat brdampak pada pekerjaan dan kehidupan sehari-hari. Dan juga dapat menenagkan pikiran dengan melakukan hal-hal yang membuat tenang pikiran, serta menghindari suatu tindakan atau pekerjaan yang dapat menimbulkan emosi maupun kekesalan terhadap sesuatu.

\section{Penutup}

Erginomi adalah studi ilmiah yang mempelajari hubungan antara manusia dan tempat kerja. Ergonomi sangat penting dalam suatu pekerjaan bagi seorang perawat untuk 
melakukan tindakan dalam memberikan asuha keperawatan mau pun tindakan yanga akan diakukan terhadap pasiean. Dalam melakukan tindakan yang tidak ergonomis seorang perawat dapat mengalami kecelakaan kerja atau menimbulkan suatu kejadian yang tidak diharapkan yaitu resiko yang akan diterima perawat. Maka dari itu seorang perawat harus dapat memahami ergonomi dalam suatu pekerjaan serta untuk mengurangi kejadian yang tidak di harapkan.

Sedangkan hazard psikososial bahaya yang dapat di terima oleh seorang perawat yang dapat menimbulkan adanya stress serta membuat dampak yang buruk pada dirinya yang mempengaruhi kehidupan sehari-hari dari seorang perawat tersebut. Hal yang dapay dilakukan untuk mengurangi dakpak negatifnya adalah untuk memperhatikan suatu tindakan yang dapat membahayakan perawat serta memberikan arahan untuk mengatasi stress yang diderita oleh seorang perawat.

\section{Daftar Pustaka}

1. Aliva Kemala. (2018). Faktor psikososial lingkungan kerja (studi kasus) pada karyawan pabrik SSP PT. X. Jurnal Psikologi, 11(1), 97-108.

2. Andarini, D., dkk. (2019). IDENTIFIKASI BAHAYA PSIKOSOSIAL PADA BURUH WANITA DI PABRIK KARET. Jurnal Kesehatan, 1, 61-67.

3. Balaputra, I., \& Adi, H. S. (2017). Pengetahuan ergonomi dan postur kerja perawat pada perawatan luka dengan gangguan muskuloskeletal di dr. H. Koesnadi Bondowoso. Berita Kedokteran Masyaraka, 33(9), 445-448.

4. Fathi, A., \& Simamora, R. H. (2019, March). Investigating nurses' coping strategies in their workplace as an indicator of quality of nurses' life in Indonesia: a preliminary study. In IOP conference series: Earth and Environmental science (Vol. 248, No. 1, p. 012031). IOP Publishing.

5. Ign. Luddy Indra Purnama., dkk. (2015). Implementasi Desain Fasilitas Kerja Ergonomis untuk Menurunkan Resiko pada Postur Kerja Duduk Statis. Jurnal Rekayasa Sistem Industri, 4(1), 33-37.

6. L. Meily Kurniawidjaja., dkk. (2014). Pengendalian Risiko Ergonomi Kasus Low Back Pain pada Perawat di Rumah Sakit. MKB, 46(4), 225-233.

7. Mindhayani, I. (2020). ANALISIS RISIKO KESELAMATAN DAN KESEHATAN KERJA DENGAN METODE HAZOP DAN PENDEKATAN ERGONOMI (STUDI KASUS: UD. BAROKAH BANTUL). Jurnal SIMETRIS, 11(1), 31-38. 
8. Nilamsari, N., dkk. (2015). ROTOTYPE BANGKU ERGONOMIS UNTUK MEMPERBAIKI POSISI DUDUK SISWA SMAN DI KABUPATEN GRESIK. Jurnal Ners, 10(1), 87-103.

9. Ningsih, S. O. D., \& Shinta, W. H. (2019). ANALISIS RESIKO KESELAMATAN DAN KESEHATAN KERJA (K3) DENGAN MENGGUNAKAN METODE HAZARD AND OPERABILITY STUDY (HAZOP) PADA BAGIAN HYDROTEST MANUAL DI PT. CLADTEK BI METAL MANUFACTURING. Journal of Business Administration, 3(1), 29-39.

10. Simamora, R. H. (2020). Learning of Patient Identification in Patient Safety Programs Through Clinical Preceptor Models. Medico Legal Update, 20(3), 553-556.

11. Prapti, N. K. G. P., dkk. (2018). KAJIAN ERGONOMI PADA TINDAKAN KEPERAWATAN DI IRD RS UNIVERSITAS UDAYANA, BADUNG, BALI. Jurnal Keperawatan Respati Yogyakarta, 5(3), 414-419.

12. Pertiwi., dkk. (2019). Hazard identification, risk assesment and risk control serta penerapan risk mapping pada Rumah Sakit Hewan Prof. Soeparwi Universitas Gadjah Mada. Berita Kedokteran Masyarakat, 35(2), 55-64. 